\title{
半導体パッケージの界面接着不良 \\ Interfacial Adhesion Failure in Semiconductor Packages
}

\author{
雨 海 正 純 $^{*}$ \\ Masazumi AMAGAI
}

\section{1.はじめに}

半導体パッケージは, 高機能, 小型化, 低コストとい う電子機器及び半導体デバイスの高機能や高速性などの 性能を最大限引き出すため, 基板への実装部品として重 要な役割を担っている。それに伴ってパッケージのI／ $\mathrm{O}$ ピン数の増加, サイズの小型化, 軽量化, 薄型化を 同時に達成することを必要としている。この要求を満た すために新しい技術である Chip Scale Package (CSP) の導入がはかられてきた。Chip Scale Package (CSP) は, 金属, セラミックス, プラスチックス等の無機及び 有機材料が多く使用されており, その構造は極めて複雑 でかつ異種材料接着接合よりなる。強度信頼性の諸問題 は多岐にわたるが，はんだリフロー工程および温度サイ クルテスト後のパッケージ界面剥離問題が顕著に現れる。 界面破壊は, 吸湿した水分の蒸気圧および異種材料間の 熱応力により, 応力特異性の大きさが原因である。界面 破壊に関する論文は数多く出されているが, ポリイミド 材を塗布したチップ表面とエポキシ封止樹脂との界面剥 離およびポリイミド表面化学・性状が界面破壊に及ぼす 影響が議論不足である。そこで, 本研究では化学結合エ ネルギーと物理単位が等価なエネルギー解放率 (G) の 関数である 応力拡大係数を用いて, 今まで論議されて こなかったポリイミド表面化学・性状がポリイミド材・ エポキシ封止樹脂界面の界面破壊勒性值に与える影響を 評価した。ポリイミド材・エポキシ封止樹脂界面破壊試 験実施後, 有限要素法による応力特異場解析で界面破壊 勒性值を求めた。また, ポリイミド表面化学・性状は,

*日本テキサスインスッルメンッ(锹パッケージ開発部

大分県速見郡日出町川崎 4260 于 879-1595

Texas Instruments Japan

4260 Kawasaki, Hiji-machi, Hayami-gun, Oita 879-1505 Japan
$\mathrm{X}$ 線光電子分光法 (XPS), 赤外分光内部反射法 (ATR) および原子間力顕微鏡（AFM）を用いて特性化を試み た。

\section{2. 評価方法}

PMDA-ODA，BTDA-ODA および ODPA-ODA の 3 種類のポリイミドを使用した。それぞれのポリイミ ドの骨格構造を図 1 に示す。厚さ約 $20 \mu \mathrm{m}$ のポリイミ ドワニスをシリコンウエハ上にスピンコート法を用いて 梁布した。その後, 紫外線で仮硬化後, 350,370 およ

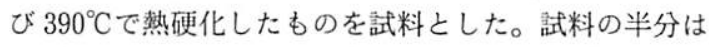
$\mathrm{CF}_{4} / \mathrm{O}_{2}$ プラズマで表面を改質した。各試料のガラス転移 温度, 破壊強度, 伸び, 密度および $5 \%$ 重量減少温度を 測定した。その結果を表 1 に示す。エポキシ樹脂を硬化 後の厚み約 $10 \mu \mathrm{m}$ のポリイミド表面に大きさ $2 \times 2 \times 3 \mathrm{~mm}$ で成形後, $175^{\circ} \mathrm{C} て ゙ 5$ 時間硬化させた。エポキシ樹脂と ポリイミド表面との間の接着強度を図 2 に示した方法で 評価した。界面破壊開始の接着強度を測定後, 有限要素 法を用いて界面の応力拡大係数を算出した。

ポリイミド表面の表面状態を X 線光電子分光装置 (XPS), 表面形態を原子間力顕微鏡 (AFM) および表 面近傍の構造を赤外分光内部反射装置 (ATR) により 観察した。

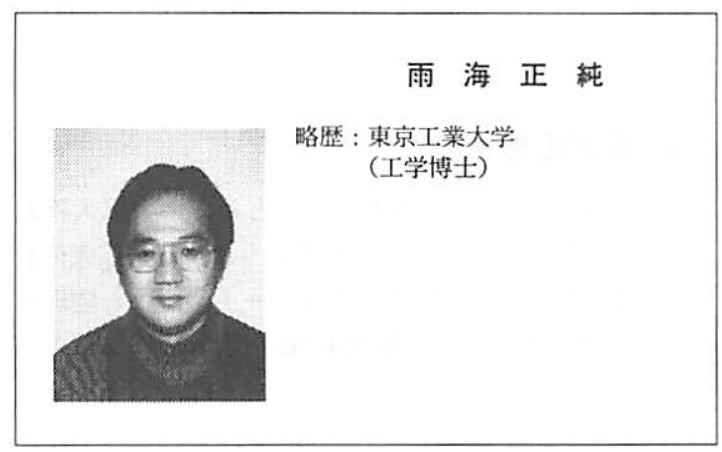




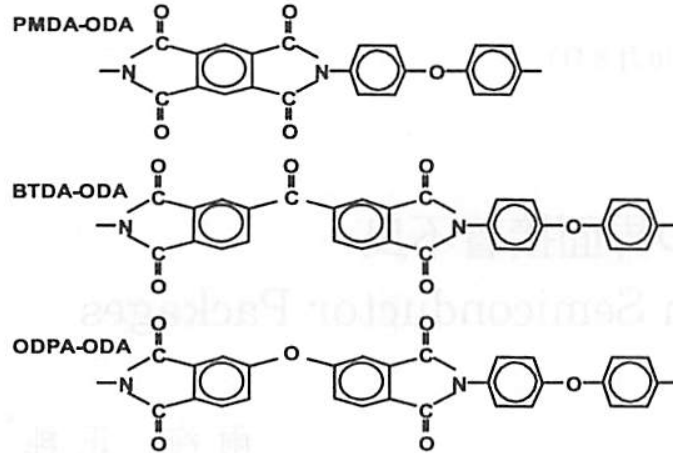

図1 ポリイミドの骨格構造

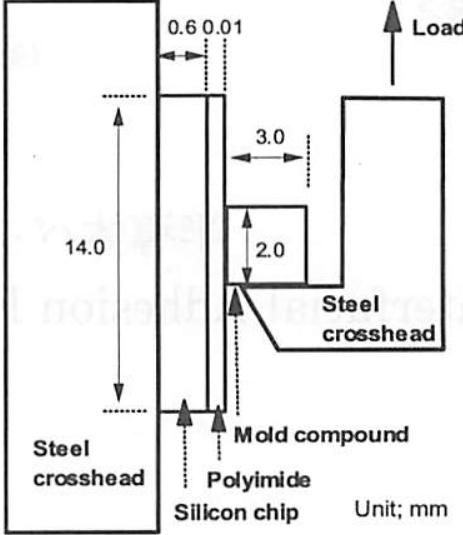

図 2 界面強度試験
表 1 各陚料の特性

\begin{tabular}{|c|c|c|c|c|c|c|c|}
\hline Polyimide & $\begin{array}{l}\text { Cure temp } \\
\left({ }^{\circ} \mathrm{C}\right)\end{array}$ & Plasma & $5 \% \mathrm{Wt}$ & $\begin{array}{l}\mathrm{Tg} \\
\left({ }^{\circ} \mathrm{C}\right)\end{array}$ & $\begin{array}{c}\text { Elongation } \\
(\%)\end{array}$ & $\begin{array}{c}\text { Fracture } \\
(\mathrm{MPa})\end{array}$ & $\begin{array}{l}\text { Density } \\
\left(\mathrm{g} / \mathrm{cm}^{2}\right)\end{array}$ \\
\hline \multirow[t]{6}{*}{ PMDA-ODA } & 350 & $\mathrm{CF}_{4} / \mathrm{O}_{2}$ & 491 & 371 & 25 & 119 & 1.408 \\
\hline & 350 & & 495 & 371 & 32 & 123 & 1.407 \\
\hline & 370 & $\mathrm{CF}_{4} / \mathrm{O}_{2}$ & 553 & 384 & 21 & 118 & 1.412 \\
\hline & 370 & & 548 & 392 & 26 & 126 & 1.412 \\
\hline & 390 & $\mathrm{CF}_{4} / \mathrm{O}_{2}$ & 576 & 410 & 18 & 121 & 1.417 \\
\hline & 390 & & 576 & 411 & 23 & 131 & 1.418 \\
\hline \multirow[t]{6}{*}{ BTDA-ODA } & 350 & $\mathrm{CF}_{4} / \mathrm{O}_{2}$ & 521 & 358 & 19 & 150 & 1.398 \\
\hline & 350 & & 516 & 358 & 23 & 154 & 1.397 \\
\hline & 370 & $\mathrm{CF}_{4} / \mathrm{O}_{2}$ & 558 & 382 & 27 & 153 & 1.399 \\
\hline & 370 & & 557 & 383 & 39 & 160 & 1.399 \\
\hline & 390 & $\mathrm{CF}_{4} / \mathrm{O}_{2}$ & 565 & 405 & 43 & 165 & 1.398 \\
\hline & 390 & & 566 & 407 & 51 & 177 & 1.397 \\
\hline \multirow[t]{6}{*}{ ODPA-ODA } & 350 & $\mathrm{CF}_{4} / \mathrm{O}_{2}$ & 505 & 237 & 70 & 140 & 1.365 \\
\hline & 350 & & 512 & 236 & 72 & 147 & 1.364 \\
\hline & 370 & $\mathrm{CF}_{4} / \mathrm{O}_{2}$ & 562 & 247 & 93 & 172 & 1.369 \\
\hline & 370 & & 561 & 246 & 77 & 160 & 1.368 \\
\hline & 390 & $\mathrm{CF}_{4} / \mathrm{O}_{2}$ & 569 & 251 & 78 & 163 & 1.369 \\
\hline & 390 & & 570 & 251 & 77 & 167 & 1.370 \\
\hline
\end{tabular}

$$
\begin{aligned}
& G=\frac{\left(1-\gamma^{2}\right)}{E^{*}} K^{2} \\
& E^{*}=\frac{2 E_{l} E_{l l}}{\left(E_{l}+E_{l l}\right)} \\
& \gamma=\frac{1}{2} \frac{\mu_{l}\left(1-2 m_{l l}\right)-\mu_{l l}\left(1-2 m_{l}\right)}{\mu_{l}\left(1-m_{l l}\right)+\mu_{l l}\left(1-m_{l}\right)}
\end{aligned}
$$

ここで $\mathrm{E}_{\mathrm{l}}, \mathrm{E}_{\mathrm{ll}}, \mu_{\mathrm{l}}, \mu_{\mathrm{II}}$, および $\mathrm{m}_{\mathrm{l}}, \mathrm{m}_{\mathrm{II}}$ は, 縦弾性率, せん断弾性率, ポアソ ン比であり，Iおよび II は界面異種材 料を示す。しかしながら, エネルギー 解放率 $(\mathrm{G})\left(\mathrm{J} / \mathrm{m}^{2}\right)$ は, 計算過程で 界面を囲む材料の物性の影兓を含んで しまう為, 緟密には界面の接着強度を 示していない。そこで,この評価では, 界面応力から直接求める応力拡大係数 （K）を用いた。式 (4)-（5）に示すよ うに, 界面応力成分 $\sigma \theta, \tau \mathrm{r} \theta$ および界 面の応力特異場の次数 $\mathrm{p}$ から界面の 応力拡大係数 $(\mathrm{K})$ を算出する。

$$
\begin{aligned}
& \sigma_{\theta}^{\mathrm{j}}=\mathrm{k}^{\mathrm{j}} \mathrm{r}^{\mathrm{p}-1} \mathrm{f}^{\mathrm{j}}(\theta) \\
& \tau_{\mathrm{r} \theta}^{\mathrm{j}}=\mathrm{k}^{\mathrm{j}} \mathrm{r}^{\mathrm{p}-1} \mathrm{~g}^{\mathrm{j}}(\theta) \\
& \sigma_{\mathrm{r}}^{\mathrm{j}}=\mathrm{k}^{\mathrm{j}} \mathrm{r}^{\mathrm{p}-1}\left\{\mathrm{~h}^{\mathrm{j}}(\theta)-\mathrm{f}^{\mathrm{j}}(\theta)\right\}
\end{aligned}
$$

\section{3. 界面接着強度}

界面接着強度を示す指標の 1 つとして応力拡大係数 (K) がある。式 (1)-(3) に示すように, 応力拡大係数 (K) は 界面の化学結合エネルギー $\left(\mathrm{J} / \mathrm{m}^{2}\right)$ と物理的 単位が等価なエネルギー解放率 $(\mathrm{G})\left(\mathrm{J} / \mathrm{m}^{2}\right)$ の関数であ る。 ここで，j は界面異種材料 I または II, r, $\theta_{\mathrm{r}}$ は界面接着 端部加の距離と角度, $\sigma, \tau$ は引っ張り応力, せん断応 力である。 $\mathrm{K}$ は応力拡大係数, $\mathrm{p}$ は応力特異場の次数で ある。これらは図 3 に示す。 $\mathrm{p}$ が $0<\mathrm{p}<1$ の場合, 応力 は指数関数的に無限大になる。

$$
\begin{array}{ll}
0<p<1 & \text { 応力特異場 } \\
p=1 \text { or } p>1 & \text { 応力特異場でない }
\end{array}
$$




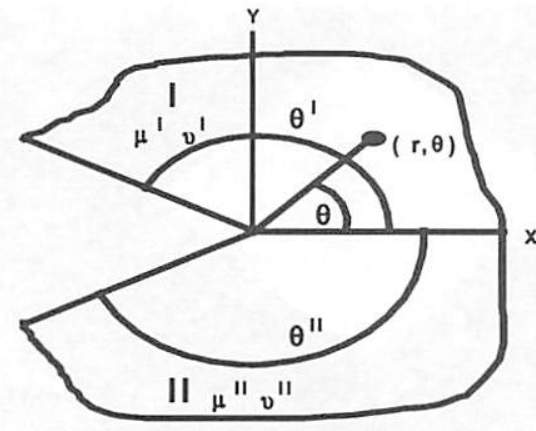

図 3 界面端部

円筒座標系の応力 $\sigma \mathrm{r}, \sigma \theta$ および $\tau \mathrm{r} \theta$ は 式 (7) - (9) を 用い 直交座標系の応力 $\sigma x, \sigma y$ および $\tau x y$ から求める。

$$
\begin{aligned}
& \sigma r=\sigma x \cos ^{2} \theta+\sigma y \sin ^{2} \theta+\tau x y \sin ^{2} \theta \\
& \sigma \theta=\sigma x \sin ^{2} \theta+\sigma y \cos ^{2} \theta-\tau x y \sin 2 \theta \\
& \tau r \theta=1 / 2(\sigma y-\sigma x) \sin 2 \theta+\tau x y \cos 2 \theta
\end{aligned}
$$

応力特異場の次数 $\mathrm{p}$ は, 特性方程式 (10) 加算出する。

$$
\mathrm{D}\left(\theta^{1}, \theta^{11}, \alpha, \beta ; \mathrm{P}\right)=0
$$

ここで, $\theta \mathrm{I}, \theta \mathrm{II}$ は異種材料 I, II の接着角度, $\alpha, \beta$ は Dunders' のパラメータである。 $\alpha, \beta$ は式 (11)-(13) か ら求まる。

$$
\begin{aligned}
\alpha= & \left(\mu^{\mathrm{II}} \mathrm{m}^{1}-\mu^{\mathrm{l}} \mathrm{m}^{\mathrm{II}}\right) /\left(\mu^{\mathrm{II}} \mathrm{m}^{1}+\mu^{\mathrm{I}} \mathrm{m}^{\mathrm{II}}\right) \\
\beta= & \left\{\mu^{\mathrm{II}}\left(\mathrm{m}^{\mathrm{I}}-2\right)-\mu^{\mathrm{I}}\left(\mathrm{m}^{\mathrm{II}}-2\right)\right\} /\left(\mu^{\mathrm{II}} \mathrm{m}^{1}+\mu^{1} \mathrm{~m}^{\mathrm{II}}\right) \\
\mathrm{m}= & 4(1-\nu) \text { (plane strain), } \\
& 4 /(1+\nu) \text { (Plane stress) }
\end{aligned}
$$

ここで, $\mu \mathrm{I}, \mu \mathrm{II}$, および $\mathrm{mI}, \mathrm{mII}$ は剛性弾性率, ポアン ン比, I, II は異種材料を示す。式 (10) は, 90 度の接着 角度の場合, 式 (14) に表すことが出来る。

$$
\begin{aligned}
& 16\left(\sin ^{2}\left(\theta^{\mathrm{I}} \mathrm{p}\right)-\mathrm{p}^{2} \sin ^{2} \theta^{\mathrm{I}}\right)\left(\sin ^{2}\left(\theta^{\mathrm{II}} \mathrm{p}\right)-\mathrm{p}^{2} \sin ^{2} \theta^{\mathrm{II}}\right) \cdot \beta^{2} \\
& +\left[16 \mathrm{p}^{2} \sin ^{2} \theta^{\mathrm{I}}\left\{\sin ^{2}\left(\theta^{\mathrm{II}} \mathrm{p}\right)-\mathrm{p}^{2} \sin ^{2} \theta^{\mathrm{II}}\right\}\right. \\
& \left.+16 \mathrm{p}^{2} \sin ^{2} \theta^{\mathrm{II}}\left\{\sin ^{2}\left(\theta^{\mathrm{I}} \mathrm{p}\right)-\mathrm{p}^{2} \sin ^{2} \theta^{\mathrm{I}}\right\}\right] \cdot \alpha \beta \\
& +\left[16 \mathrm{p}^{2}\left(\mathrm{p}^{2}-1\right) \sin ^{2} \theta^{\mathrm{I}} \sin ^{2} \theta^{\mathrm{II}}-4\left\{\mathrm{p}^{2} \sin ^{2}\left(\theta^{1}+\theta^{\mathrm{II}}\right)\right.\right. \\
& \left.\left.-\sin ^{2} \mathrm{p}\left(\theta^{\mathrm{I}}+\theta^{\mathrm{II}}\right)\right\}\right] \cdot \alpha^{2} \\
& +16 \mathrm{p}^{2}\left[\sin ^{2} \theta^{\mathrm{I}} \sin ^{2}\left(\theta^{\mathrm{II}} \mathrm{p}\right)-\sin ^{2} \theta^{\mathrm{II}} \sin ^{2}\left(\theta^{\mathrm{I}} \mathrm{p}\right)\right] \cdot \beta \\
& +8\left[-2 \mathrm{p}^{2}\left\{\sin ^{2} \theta^{1} \sin ^{2}\left(\theta^{\mathrm{II}} \mathrm{p}\right)-\sin ^{2} \theta^{\mathrm{II}} \sin ^{2}\left(\theta^{\mathrm{I}} \mathrm{p}\right)\right\}\right. \\
& +\left\{\sin ^{2}\left(\theta^{\mathrm{II}} \mathrm{p}\right)-\mathrm{p}^{2} \sin ^{2} \theta^{\mathrm{II}}\right\}-\left\{\sin ^{2}\left(\theta^{\mathrm{I}} \mathrm{p}\right)\right. \\
& \left.\left.-\mathrm{p}^{2} \sin ^{2} \theta^{\mathrm{I}}\right\}\right] \cdot \alpha-4 \mathrm{p}^{2} \sin ^{2}\left(\theta^{1}-\theta^{\mathrm{II}}\right) \\
& +4 \sin ^{2} \mathrm{p}\left(\theta^{1}-\theta^{\mathrm{II}}\right)=0
\end{aligned}
$$

各ポリイミドサンプルとエポキシ樹脂の接着力を図 2 で 示した方法で求めた。界面破壊に至る荷重を接着試験で 求め, その荷重力を有限要素法に導入し 応力拡大係数 を算出した。BTDA-ODA ポリイミドをプラズマエッ チしたサンプルとエポキシ樹脂の界面応力 $\sigma r, \sigma \theta$ およ

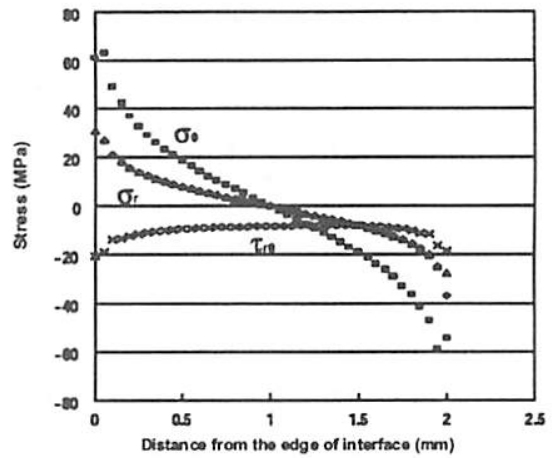

図4 界面応力と接着端部からの距離の関係

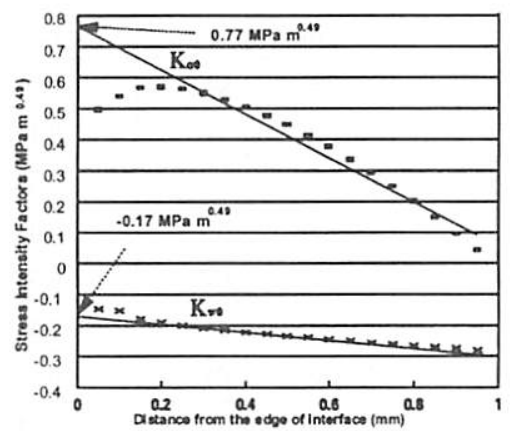

図 5 応力拡大係数之接着端部からの距離の関係

び $\tau \mathrm{r} \theta$ と接着端部からの距離の関係を図 4 に示す。応 力拡大係数と接着端部からの距離の関係を図 5 に示す。 BTDA-ODA ポリイミドとエポキシ樹脂の特異場の次 数は 0.49 である。接着端部での応力拡大係数は, 周辺 距離からの外挿で求めた。BTDA-ODA ポリイミドを プラズマエッチしたサンプルとエポキシ樹脂の接着端部 での応力拡大係数は, 外挿法で $0.77\left(\mathrm{MPm}^{0.49}\right)$ となる。 各ポリイミドサンプルとエポキシ樹脂との界面の応力拡 大係数は, 表 2 に示す。 $\mathrm{CF}_{4} / \mathrm{O}_{2}$ プラズマエッチしたポ リイミト゚サンプルは $\mathrm{CF}_{4} / \mathrm{O}_{2}$ プラズマエッチしないサン プルに比へ 界面の応力拡大係数が $2-3$ 倍になること が判明した。ポリイミドの硬化温度は 密着力に大きく 寄与していないことが分かった。

\section{4. 表面性状と密着力の関係}

原子間力顕微鏡 $(\mathrm{AFM})$ を用いて, 各ポリイミドサン プルの表面性状を钼察した。各ポリイミドサンプルの $\mathrm{Ra}, \mathrm{Rmax}$ ，および単位面積あたりの表面粗さを求めた。 $\mathrm{Ra}$ は 測定した距離の表面粗さの平均を示す。各ポリ イミドサンプルの Ra は， 0.2 から $4 \mathrm{~nm}$ の範囲に入る。 $R \max$ は 測定した距離の範囲で最大の表面粗さを示 す。各ポリイミドサンプルの $\mathrm{Rmax}$ は， 4 から $60 \mathrm{~nm}$ 
表 2 各ポリイミドとエポキシ樹脂との界面応力拡大係数

\begin{tabular}{|c|c|c|c|}
\hline Polyimide & $\begin{array}{l}\text { Cure temp } \\
\left({ }^{\circ} \mathrm{C}\right)\end{array}$ & Plasma & $\mathrm{K}_{o \mathrm{e}}\left(\mathrm{MPam}^{1-p}\right)$ \\
\hline \multirow[t]{6}{*}{ PMDA-ODA } & 350 & $\mathrm{CF}_{4} / \mathrm{O}_{2}$ & 0.57 \\
\hline & 350 & & 0.29 \\
\hline & 370 & $\mathrm{CF}_{4} / \mathrm{O}_{2}$ & 0.55 \\
\hline & 370 & & 0.19 \\
\hline & 390 & $\mathrm{CF}_{4} / \mathrm{O}_{2}$ & 0.55 \\
\hline & 390 & & 0.26 \\
\hline \multirow[t]{6}{*}{ BTDA-ODA } & 350 & $\mathrm{CF}_{4} / \mathrm{O}_{2}$ & 0.77 \\
\hline & 350 & & 0.42 \\
\hline & 370 & $\mathrm{CF}_{4} / \mathrm{O}_{2}$ & 0.66 \\
\hline & 370 & & 0.37 \\
\hline & 390 & $\mathrm{CF}_{4} / \mathrm{O}_{2}$ & 0.58 \\
\hline & 390 & & 0.45 \\
\hline \multirow[t]{6}{*}{ ODPA-ODA } & 350 & $\mathrm{CF}_{4} / \mathrm{O}_{2}$ & 0.56 \\
\hline & 350 & & 0.33 \\
\hline & 370 & $\mathrm{CF}_{4} / \mathrm{O}_{2}$ & 0.64 \\
\hline & 370 & & 0.27 \\
\hline & 390 & $\mathrm{CF}_{4} / \mathrm{O}_{2}$ & 0.45 \\
\hline & 390 & & 0.24 \\
\hline
\end{tabular}

の範囲に入る。単位面積あたりの表面粗さは, $4 \times 4 \mu \mathrm{m}$ の範囲で測定した粗さの総和を面積で割った值である。 各ポリイミドサンプルの単位面積あたりの表面粗さは, 0.05-9nm/ $\mu \mathrm{m}^{2}$ の範囲に入る。PMDA-ODA ポリイ ミドにプラズマエッチしないサンプルの表面性状は，図 6-a に示す。PMDA-ODA ポリイミドにプラズマエッ チしたサンプルの表面性状は，図 6-b に示す。図 6 を 比較すれば分かるように ポリイミドにプラズマエッチ したサンプルは，表面粗さが增加した。表 3 に示す様に， プラズマエッチしないPMDA-ODA, BTDA-ODA お よび ODPA-ODA の表面粗さ Ra は，それぞれ 0.29$0.33,1.44-1.63,0.79-0.90 \mathrm{~nm}$ の範囲にある。プラズマ エッチした PMDA-ODA, BTDA-ODA および ODPA -ODA の表面粗さ Ra は，それぞれ 3.31-3.88，2.733.43 および $3.61-4.08 \mathrm{~nm}$ の範囲にある。プラズマエッ チしたポリイミド表面粗さは，プラズマエッチしていな いのに比へ 2-15 倍になる。しかしながら，ポリイミド 表面粗さ $\mathrm{Ra}$ は，最大值 3-4nm でそれ以上にならない ことが判明した。図 7 は，ポリイミド表面粗さ $\mathrm{Ra}$ と界 面の臨界応力拡大係数（界面破壊勒性值）上の関係を示 す。ポリイミド表面粗さ $\mathrm{Ra}$ は，ポリイミド表面とエポ キシ樹脂の密着力に大きく寄与していることが分かった。

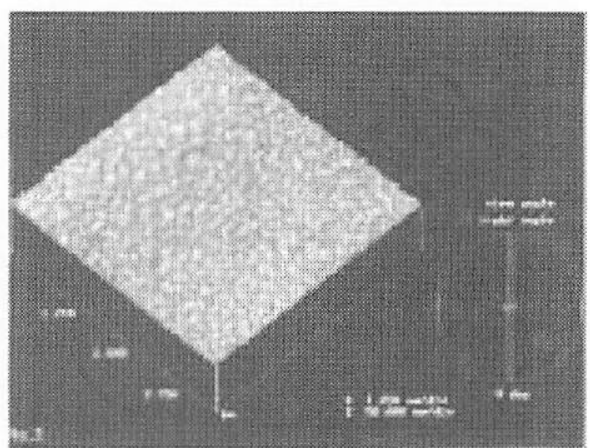

(a) プラズマ処理無し

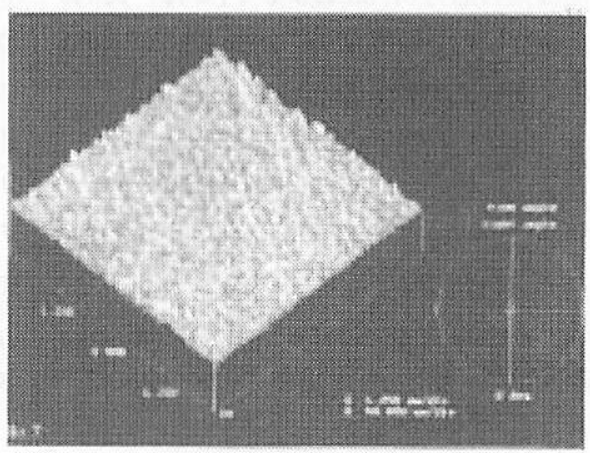

(b) プラズマ処理有り

図 6 PMDA-ODA ポリイミド表面性状

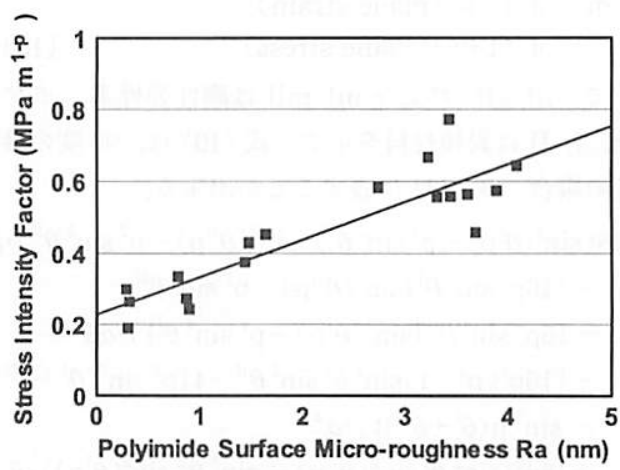

図 7 ポリイミド表面粗さ $\mathrm{Ra}$ と界面の臨界応力拡大係数

\section{5. 表面化学と密着力の関係}

ポリイミド表面化学と密着力の関係を調べる為, $\mathrm{X}$ 線光電子分光装置 (XPS) を用いて, ポリイミド表面を 観察した。図 8a は, PMDA-ODA ポリイミドの単体 分子構造および XPS 钼察で出現するピーク值の結合エ ネルギー $(\mathrm{eV})$ を示す。PMDA-ODA ポリイミド表面 に $\mathrm{CF}_{4} / \mathrm{O}_{2}$ プラズマエッチした場合とプラズマエッチし 
表 3 ポリイミド表面粗さ（Ra）

\begin{tabular}{|c|c|c|c|}
\hline Polyimide & $\begin{array}{l}\text { Cure temp } \\
\quad\left({ }^{\circ} \mathrm{C}\right)\end{array}$ & Plasma & $\begin{array}{c}\text { Micro-roughness } \\
\operatorname{Ra}(\mathrm{nm})\end{array}$ \\
\hline \multirow[t]{6}{*}{ PMDA-ODA } & 350 & $\mathrm{CF}_{4} / \mathrm{O}_{2}$ & 3.884 \\
\hline & 350 & & 0.288 \\
\hline & 370 & $\mathrm{CF}_{4} / \mathrm{O}_{2}$ & 3.438 \\
\hline & 370 & & 0.303 \\
\hline & 390 & $\mathrm{CF}_{4} / \mathrm{O}_{2}$ & 3.306 \\
\hline & 390 & & 0.317 \\
\hline \multirow[t]{6}{*}{ BTDA-ODA } & 350 & $\mathrm{CF}_{4} / \mathrm{O}_{2}$ & 3.426 \\
\hline & 350 & & 1.473 \\
\hline & 370 & $\mathrm{CF}_{4} / \mathrm{O}_{2}$ & 3.222 \\
\hline & 370 & & 1.436 \\
\hline & 390 & $\mathrm{CF}_{4} / \mathrm{O}_{2}$ & 2.734 \\
\hline & 390 & & 1.636 \\
\hline \multirow[t]{6}{*}{ ODPA-ODA } & 350 & $\mathrm{CF}_{4} / \mathrm{O}_{2}$ & 3.605 \\
\hline & 350 & & 0.788 \\
\hline & 370 & $\mathrm{CF}_{4} / \mathrm{O}_{2}$ & 4.081 \\
\hline & 370 & & 0.87 \\
\hline & 390 & $\mathrm{CF}_{4} / \mathrm{O}_{2}$ & 3.68 \\
\hline & 390 & & 0.896 \\
\hline
\end{tabular}

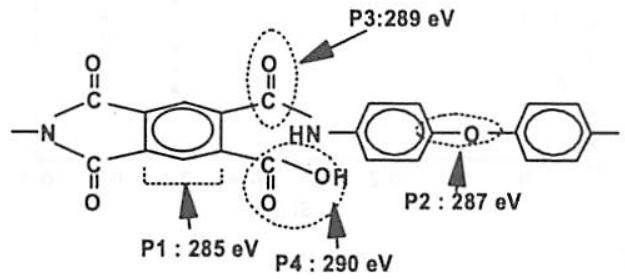

図 8a PMDA-ODA ポリイミドとXPSのエネルギー

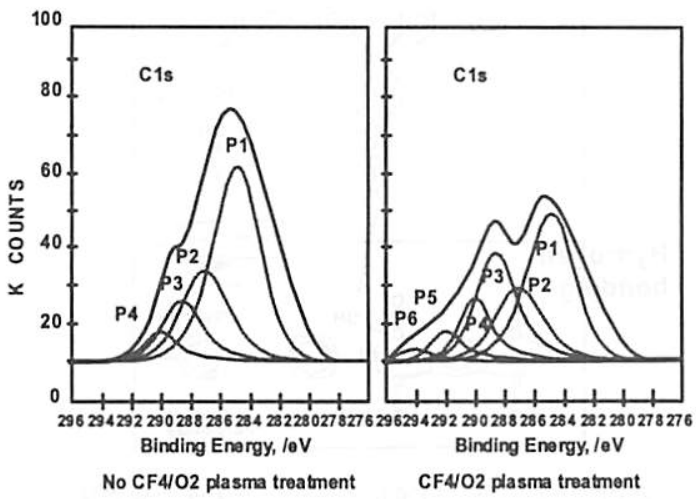

図 8b プラズマ処理有り無しと結合エネルギーの変化
表 4 カーボキシル基とカーボニル基

\begin{tabular}{|c|c|c|c|c|}
\hline Polyimide & $\begin{array}{l}\text { Cure temp } \\
\left({ }^{\circ} \mathrm{C}\right)\end{array}$ & Plasma & $\begin{array}{c}\text { The amount } \\
\text { of } \mathrm{C}=\mathrm{O} \text { and } \\
\mathrm{COO}(\%)\end{array}$ & $\begin{array}{l}\mathrm{Si} \\
(\%)\end{array}$ \\
\hline \multirow[t]{6}{*}{ PMDA-ODA } & 350 & $\mathrm{CF}_{4} / \mathrm{O}_{2}$ & 15.8 & 0.5 \\
\hline & 350 & & 15.7 & 0.5 \\
\hline & 370 & $\mathrm{CF}_{4} / \mathrm{O}_{2}$ & 18.4 & 0.5 \\
\hline & 370 & & 15.7 & 0.5 \\
\hline & 390 & $\mathrm{CF}_{4} / \mathrm{O}_{2}$ & 18.5 & 0.3 \\
\hline & 390 & & 15.9 & 0.3 \\
\hline \multirow[t]{6}{*}{ BTDA-ODA } & 350 & $\mathrm{CF}_{4} / \mathrm{O}_{2}$ & 18.3 & 0.2 \\
\hline & 350 & & 16 & 0.5 \\
\hline & 370 & $\mathrm{CF}_{4} / \mathrm{O}_{2}$ & 18.4 & 0.2 \\
\hline & 370 & & 15.4 & 0.6 \\
\hline & 390 & $\mathrm{CF}_{4} / \mathrm{O}_{2}$ & 18.6 & 0.2 \\
\hline & 390 & & 14.4 & 0.5 \\
\hline \multirow[t]{6}{*}{ ODPA-ODA } & 350 & $\mathrm{CF}_{4} / \mathrm{O}_{2}$ & 19 & 0.2 \\
\hline & 350 & & 17.2 & 0.6 \\
\hline & 370 & $\mathrm{CF}_{4} / \mathrm{O}_{2}$ & 19.1 & 0.1 \\
\hline & 370 & & 16 & 0.6 \\
\hline & 390 & $\mathrm{CF}_{4} / \mathrm{O}_{2}$ & 17.9 & 0.4 \\
\hline & 390 & & 15.2 & 0.5 \\
\hline
\end{tabular}

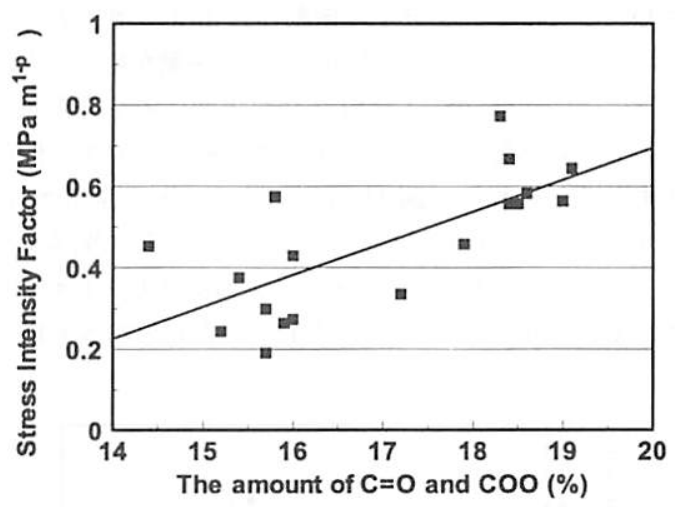

図 9 応力拡大係数とカーボニル基・カーボキシル基の 総和の関係

ない場合の XPS ピーク値の比較を図 $8 \mathrm{~b}$ に示す。 $\mathrm{C}=\mathrm{C}$, $\mathrm{C}-\mathrm{O}$ お 上び $\mathrm{C}-\mathrm{N}, \mathrm{C}=\mathrm{O}, \mathrm{COO}$ の各結合のピーク值は, それぞれ $285 \mathrm{eV}, 287 \mathrm{eV}, 289 \mathrm{eV}, 290 \mathrm{eV}$ で出現する。 ポリイミド表面に分布したカーボニル基㧍よびカーボキ シル基の総和，シリコンの含有率を表 4 に示す。プラズ マエッチした場合, カーボニル基およびカーボキシル基 の総和が增加することが判明した。また, ポリイミドの 


\section{Chemical bond energy ( $\mathrm{kcal} / \mathrm{mol}$ ) \\ C-N 69.7 \\ C-C 83.1 \\ C-O 84.0 \\ $\mathrm{N}-\mathrm{H} \quad 93.4$ \\ C-H 98.8 \\ C-F 105.4 \\ $\mathrm{C}=\mathrm{N} \quad 142.0$ \\ $\mathrm{C}=\mathrm{C} \quad 146.0$}

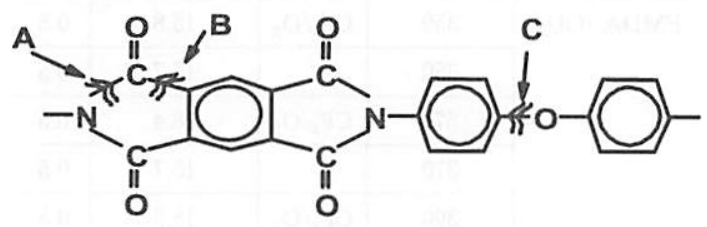

図 10 切机易い化学結合

硬化温度は, ポリイミド表面の化学状態に大きく寄与し ていないことが分かった。図 9 は, 界面破壊臨界の応力 拡大係数とカーボニル基およびカーボキシル基の総和の 関係を示す。ポリイミド表面にカーボニル基书よびカー ボキシル基が多く分布した場合，ポリイミド樹脂表面 とエポキシ樹脂の密着力が向上することが分かった。ポ リイミドの $\mathrm{N}-\mathrm{C} 6 \mathrm{H} 6-\mathrm{O}$ 分子は, 平面構造に配列して いて, 振動し難い構造になっている。図 10 に示すよう に, ポリイミドの $\mathrm{C}-\mathrm{N}, \mathrm{C}-\mathrm{C}, \mathrm{C}-\mathrm{O}$ 結合は, 結合エネ ルギーか弱く, プラズマやプロセス条件で 切断され易 い。C-N, C-C, C-O 結合が切断されたことにより, $\mathrm{N}-\mathrm{C} 6 \mathrm{H} 6-\mathrm{O}$ 分子に拘束されていた $\mathrm{C} 6 \mathrm{H} 6$ 分子の振動の 自由度が增加する。さらに, C-N, C-C, C-O 結合か 切断されたことにより, ポリイミド結合で拘束されてい た $\mathrm{O}=\mathrm{C}-\mathrm{N}, \mathrm{C}=\mathrm{O}$ 分子の振動の自由度が增加する。 これにより，ポリイミド表面の分子の振動が増加すると 同時に, $\mathrm{C}-\mathrm{O}$ 結合, $\mathrm{C}=\mathrm{O}$ 結合が表面に多く分布する ことで, 親水性が向上し, エポキシ樹脂との濡れ性が 增すと考えられる。図 11 は, ポリイミド表面粗さ Ra とカーボニル基およびカーボキシル基の総和の関係を示 す。ポリイミド表面にカーボニル基別よびカーボキシル 基が多く分布した場合, ポリイミド表面の粗さむ増加

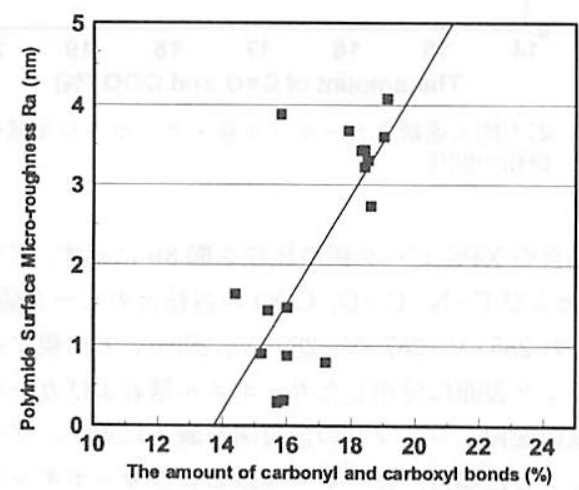

図 11 表面粗さ $\mathrm{Ra}$ とカーボニル基・カーボキシル基
することが判明した。この結果から，カーボニル基お よびカーボキシル基が ポリイミド表面の粗さを作っ ていると考えられる。ポリイミド表面に C-O 結合, $\mathrm{C}=\mathrm{O}$ 結合が多く分布した場合，エポキシ樹脂との密 着力が上がることから，ポリイミド表面は親水性，す なわち ポリイミド表面の酸素基とエポキシ樹脂の水 素基とは，水素結合で密着していることが考えられる。 図 12 は, 界面破壊臨界の応力拡大係数とポリイミド 表面に分布したシロキサン分子のシリコン元素（\%) との関係を示す。ポリイミド表面に シリコン元素す なわちシロキサン分子が多く分布した場合，ポリイミ ド樹脂表面とエポキシ樹脂の密着力は低下することが 判明した。これは, 図 13 に示すように, シロキサン 分子が ポリイミド表面の酸素基とエポキシ樹脂の水素 基の水素結合を阻害する為であると考えられる。この 考察から，ポリイミド表面の酸素基とエポキシ樹脂の 水菜基の水素結合の数が 密着力を支配していると推察 できる。

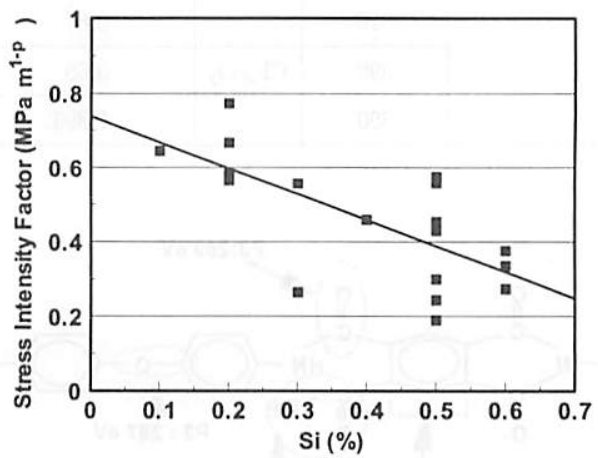

図 12 応力拡大係数とシロキサン分子のシリコン元素（\%)

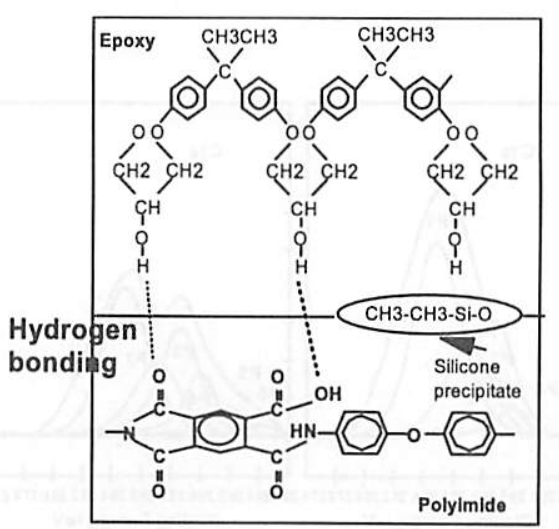

図 13 シロキサン分子がポリイミド表面の酸素基と エポキシ樹脂の水素基の水素結合を阻害 


\section{6. 分子配向と密着力の関係}

赤外分光内部反射法（ATR）を用いて, 各ポリイミ ドの分子配向を調べた。図 14 に示すょうに，赤外線入 射に対し反射した偏光を調べることで ポリイミド分子 が $\mathrm{x}-\mathrm{z}$ 平面に平行に分布しているかがわかる。分子配 向が遷移モーメントと平行であれば, 強い赤外線吸光ピー クが出現する。また, 赤外線入射角度を 0 および 90 度 にした場合, 反射偏光の比で, ポリイミド分子平面内に, $\mathrm{C}=\mathrm{O}, \mathrm{COO}$ などがあるかどうかが確認できる。図 15

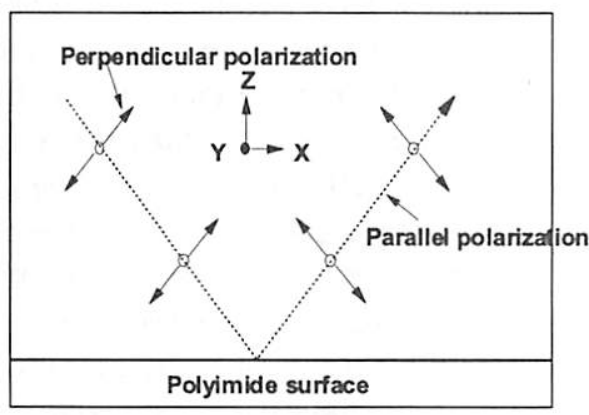

図 14 赤外線入射に対し反射した偏光

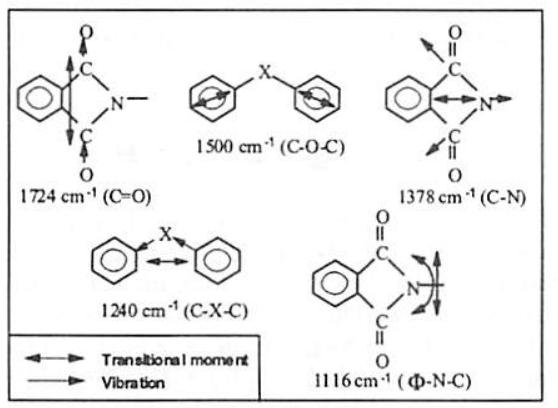

図15 ポリイミド内の各基の遷移モーメントと振動の IR 吸光ピーク

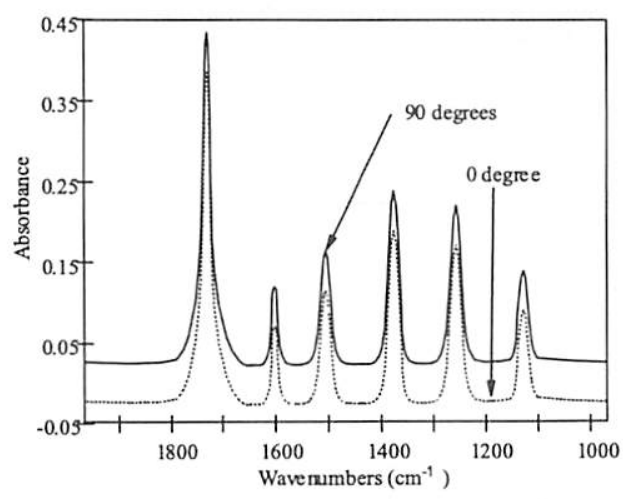

図 16 IR の入射角度 0 および 90 度にした場合, IR 偏光ピーク $\left(\mathrm{cm}^{-1}\right)$ の比
は，ポリイミド内の各基の遷移モーメントと振動の IR 吸光ピーク $\left(\mathrm{cm}^{-1}\right)$ を示したあのである。図 16 は, IR の入射角度 0 および 90 度にした場合, IR 偏光ピーク $\left(\mathrm{cm}^{-1}\right)$ の比を示したものである。1116 $\mathrm{cm}^{-1}$ はイミド 平面内の $-\mathrm{N}-\mathrm{C}$-基の振動, $1240 \mathrm{~cm}^{-1}$ は $\mathrm{ODA}$ 平面内 の ODA 間の $\mathrm{C}-\mathrm{X}-\mathrm{C}$ 非対称伸縮, $1378 \mathrm{~cm}^{-1}$ はイミト

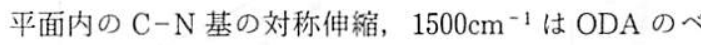
ンゼン環の $\mathrm{C}=\mathrm{C}$ 伸縮, $1724 \mathrm{~cm}^{-1}$ はイミド平面内の $\mathrm{C}=$ $\mathrm{O}$ 伸縮を示す。遷移モーメントに対する偏光の比を钼 察することで, ポリイミドの分子配向が表 5 に示すよう に決定された。ポリイミドの分子は ポリイミド表面に 対し 30-40 度傾いて配向していることが分かった。図 17 は，ポリイミドの分子配向角度とポリイミト表面・エポキ シ樹脂界面の臨界応力拡大係数（界面破壊勒性值）との 関係を示す。ポリイミドの分子配向角度は, ポリイミト 表面・エポキシ樹脂の密着性に奇与していることが判明 した。ポリイミド分子はポリイミド表面に対しジグザ クに配向してる。プラズマやプロセス条件で $\mathrm{N}-\mathrm{C} 6 \mathrm{H} 6$ $\mathrm{O}$ やイミド基に拘束されていた $\mathrm{C} 6 \mathrm{H} 6, \mathrm{C}=\mathrm{O}$ ，および $\mathrm{COO}$ 結合が切断され, ポリイミドの剛直性が綑和され る。剛直性が緩和されることにより, 分子の自由度が増 加すると共に ポリイミド表面の濡れ性が向上し ポリ

表 5 ポリイミドの分子配向

\begin{tabular}{|c|c|c|c|}
\hline Polyimide & $\begin{array}{l}\text { Cure temp } \\
\left({ }^{\circ} \mathrm{C}\right)\end{array}$ & Plasma & $\begin{array}{c}\text { Orientation } \\
\left({ }^{\circ}\right)\end{array}$ \\
\hline \multirow[t]{6}{*}{ PMDA-ODA } & 350 & $\mathrm{CF}_{4} / \mathrm{O}_{2}$ & 35 \\
\hline & 350 & & 35 \\
\hline & 370 & $\mathrm{CF}_{4} / \mathrm{O}_{2}$ & 31 \\
\hline & 370 & & 35 \\
\hline & 390 & $\mathrm{CF}_{4} / \mathrm{O}_{2}$ & 32 \\
\hline & 390 & & 36 \\
\hline \multirow[t]{6}{*}{ BTDA-ODA } & 350 & $\mathrm{CF}_{4} / \mathrm{O}_{2}$ & 29 \\
\hline & 350 & & 35 \\
\hline & 370 & $\mathrm{CF}_{4} / \mathrm{O}_{2}$ & 31 \\
\hline & 370 & & 33 \\
\hline & 390 & $\mathrm{CF}_{4} / \mathrm{O}_{2}$ & 31 \\
\hline & 390 & & 33 \\
\hline \multirow[t]{6}{*}{ ODPA-ODA } & 350 & $\mathrm{CF}_{4} / \mathrm{O}_{2}$ & 32 \\
\hline & 350 & & 34 \\
\hline & 370 & $\mathrm{CF}_{4} / \mathrm{O}_{2}$ & 33 \\
\hline & 370 & & 34 \\
\hline & 390 & $\mathrm{CF}_{4} / \mathrm{O}_{2}$ & 32 \\
\hline & 390 & & \\
\hline
\end{tabular}




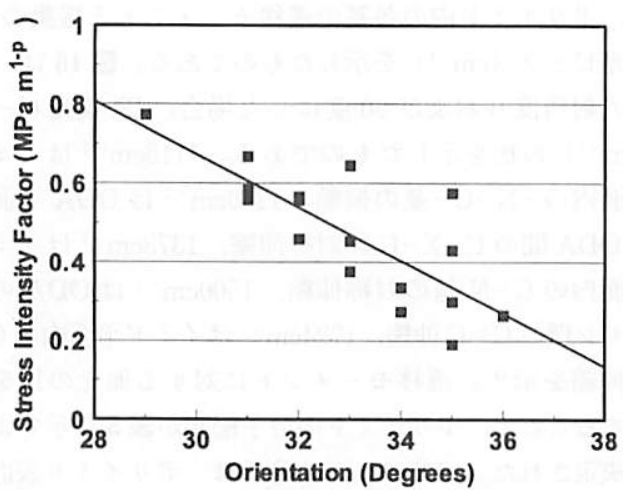

図 17 ポリイミドの分子配向角度とポリイミド表面・ エポキシ樹脂界面の臨界応力拡大係数

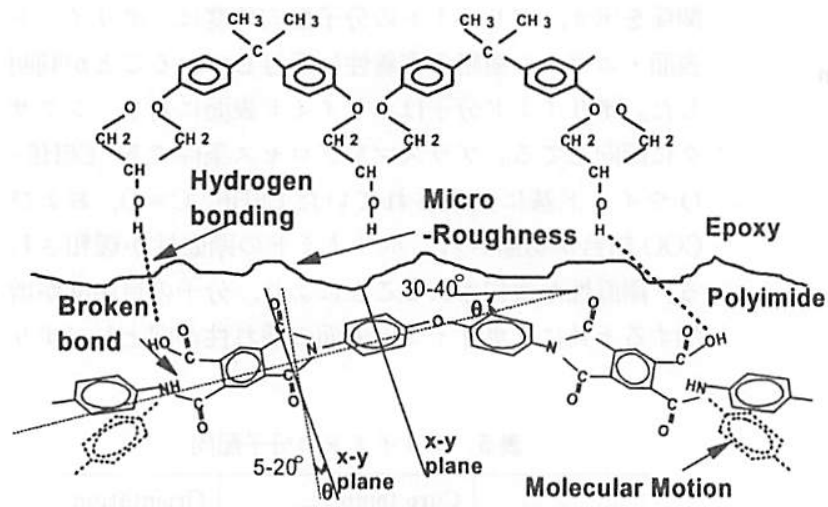

図 18 ポリイミド表面・エポキシ樹脂の密着モデル

イミド表面・エポキシ樹脂の密着性が上がる。XPS, AFM および ATR 分析結果から, ポリイミド表面・エ ポキシ樹脂の密着モデルを図 18 に提案する。ポリイミ ドの分子は ポリイミド表面に対し 30-40 度傾いて配 向，イミド基は ポリイミド表面に対し 5-25度傾い て配向している。ポリイミド表面の粗さは カーボニル 基およびカーボキシル基により作られていて，その中の 酸素基は エポキシ樹脂の水素基と水素結合で密着して
いる。カーボニル基およびカーボキシル基が作る表面の 粗さおよび水素結合の数は，ポリイミド表面・エポキシ 樹脂の密着力を決定していることが分かった。

\section{7. まとめ}

ポリイミド表面・エポキシ樹脂界面の臨界応力拡大係 数（界面破壊勒性值）の大小は, ポリイミド表面の粗さ, 水素結合および分子配向で決まる。ポリイミド分子はポ リイミド表面に対し ジグザクに配向してる。ポリイミ ドの分子は ポリイミド表面に対し 30-40度傾いて配 向，イミド基は ポリイミド表面に対し 5-25度傾い て配向している。プラズマやプロセス条件で N-C6H6$\mathrm{O}$ やイミド基に拘束されていた $\mathrm{C} 6 \mathrm{H} 6, \mathrm{C}=\mathrm{O}$ ，および $\mathrm{COO}$ 結合が切断され，ポリイミドの剛直性が緩和され る。剛直性が緩和されることにより, 分子の自 由度が增加すると共に ポリイミド表面の濡れ 性が向上し ポリイミド表面・エポキシ樹脂の 密着性が上がる。ポリイミド表面の粗さは カー ボニル基およびカーボキシル基により作られて いて，その中の酸素基は エポキシ樹脂の水素 基と水菜結合で密着している。カーボニル基お よびカーボキシル基が作る表面の粗さおよび水 素結合の数は, ポリイミド表面・エポキシ樹脂 の密着力を決定していることが分かった。

\section{参 考 文 献}

1) Kikuo Kishimoto et al, "Fracture Mechanics of Interface", Journal of the Japan Society of the Materials Science (JSMS), Vol. 48, Dec. 1999, pp. 124-129.

2) D. B. Bogy, "Two Edge Bonded Elastic Wedges of Different Materials and Wedge Angles and Surface Tractions," Journal of Appl. Mech., 1971, pp. 377-386.

3) Ryuoji Yuki, "Mechanics of Interface," Book of the Baihukan, 1993, pp. 1-283.

4) Ryoji Yuuki, Mitsuru Sato, "Mechanics of the Interface in LSI Package," Proc. Japan Soc. of Mech. Eng., Int. Sym. on Highly Advanced Computing, Aug., 1994, pp. 107-122. 